DOI https://doi.org/10.30525/978-9934-571-83-1-30

\title{
THE ROLE OF THE COURT OF JUSTICE OF THE EUROPEAN UNION IN AUTONOMIZATION OF THE EU LEGAL ORDER
}

\section{Falalieieva L. H.}

\section{INTRODUCTION}

The relevance of this study is determined by the role of jurisprudence of the Court of Justice of the EU in the execution of competence of the integration association, in the process of establishment and development of the EU law, formation and autonomization of the EU legal order. In the context of modern challenges, the study of the peculiarities of the legal status and evolution of the jurisdiction of the EU Court, the post-Lisbon period of its reformation, the latest approaches to the structure of the judicial system of integration association, the role of judicial practices in autonomization of the EU legal order, which is of great practical importance for the functioning and deepening of European integration. Simultaneously the problems of the post-Lisbon period functioning of the EU judicial system, institutional and legal mechanisms and tools for solving them, approaches to the autonomization and constitutionalization of the EU legal order, being a significant scientific interest, continue to remain studied insufficiently.

The legal rules formulated in the Court of Justice judicial decisions can be taken into account by the Ukrainian judicial organs in the process of national law interpretation in accordance with European standards and values, serving as a useful framework, reference point, but not a source of law of the national legal system, not the legal basis for regulation of relations on which the dispute arose.

The aim of the study is to highlight the specific nature of the legal status of the Court of Justice of the EU and the evolution of its jurisdiction, the reformation of the judicial system of the integration association in the postLisbon period, updating of its organizational structure and analysis hereon of methodology of the EU legal order autonomization as a multidimensional phenomenon.

\section{Genesis of the EU judicial system}

The Court of Justice of the European Coal and Steel Community (prototype of the Court of Justice of the EU) was established by the Treaty of Paris 1951 to ensure that the right was observedin the interpretation and application of the latest, as well as the rules established for the purpose of its performance (Article 
31). Simultaneously with the Treaties of Rome 1957, as foundings acts of the European Economic Community (EEC) and the European Atomic Energy Community (currently operating outside the EU, but subject to the jurisdiction of the Court of Justice of the EU), which contained provisions on the creation the judicial authorities, a Convention on certain institutions common to the European Communities was signed, which in particular envisaged the transformation of the Court of Justice of the European Coal and Steel Community into a single Court of Justice of the European Communities (now the Court), which became a joint institution of the three European Communities since 1958. With the development of integration processes and the expansion of European Communities, the burden on the Court has been steadily increasing, so with the decision of the Council of the European Communities of 24 October 1988 the Court of First Instance was established, which was a structural component of the Court of Justice of the European Communities until the entry into force of the Treaty of Nice 2001. The Treaty of Nice 2001, in fact, formed the EU judicial system, has established the optimal division of jurisdiction between the Court of Justice of the European Communities and the Court of First Instance. The possibility of establishing the Council of the EU in the Court of First Instance the court chambers with special jurisdiction as the backbone of the EU judicial system, for the first time envisaged by the Treaty of Nice 2001, was embodied only in the creation of the EU Civil Service Tribunal on November 2, 2004, which has jurisdiction over the settlement of disputes between the EU and its employees ${ }^{1}$ and functioned from December 12, 2005 to September 1, 2016. The EU Civil Service Tribunal was disbanded and integrated into the General Court by the European Parliament and EU Council Regulation (EU, Euratom) 2016/1192 of 6 July 2016 ${ }^{2}$, which simplified the structure of the Court of Justice of the EU as a judicial system of the integration association.

It is noteworthy that, with establishment of the EU, the jurisdiction of the Court was linked to the application of community law, which formed the basis of EU law. In practice, Court remained an institution that exercised jurisdiction almost exclusively within the European Community as the first pillar of the EU, not extending to new policies and forms of cooperation that constituted the second and third pillars; therefore, in official texts, it continued to be called the Court of Justice of the European Communities. Community law was enshrined

\footnotetext{
${ }^{1}$ Chalmers D., Davies G., Monti G. European Union Law: Text and Materials. 3rd ed. Cambridge : Cambridge University Press, 2014. P. 163.

${ }^{2}$ Regulation (EU, Euratom) 2016/1192 of the European Parliament and of the Council of 6 July 2016 on the transfer to the General Court of jurisdiction at first instance in disputes between the European Union and its servants. Official Journal of the European Union. L 200. 26 July 2016. P. 137-139. URL: https://eurlex.europa.eu/eli/reg/2016/1192/oj.
} 
in the founding treaties of the European Communities, namely the Treaty of Paris 1951 and the Treaties of Rome 1957, and also created by the relevant institutions (the institutional mechanism of the European Communities and the $\mathrm{EU}$, as well as their membership, were the only ones) and was a subject to jurisdictional protection, in contrast to Common Foreign and Security Policy (the second pillar of the EU) and police and judicial cooperation in criminal matters (the third pillar of the EU). The Treaty of Lisbon 2007 explicitly replaced by a homogeneous integration structure of EU the EU pillar structure introduced by the Treaty on European Union 1992 (TEU) and the successively developed by TEU as amended by the Amsterdam Treaty of 1997 and the TEU as amended by the Nice Treaty of 2001.

Due to the provision of the EU's international legal personality and the recognition of its successor in the European Community, Treaty of Lisbon 2007 the complex concept of "Court of Justice of the European Union" is introduced to refer to the extensive 3-point judicial system. It means, the Court of Justice of the EU as a system of justice, in accordance to Treaty of Lisbon 2007 has maintained a 3-point architecture: the Court (the Court of Justice, former the Court of Justice of European Communities), the General Court (former the Court of First Instance) and specialized courts (former court chambers, judicial bodies with special jurisdiction over the consideration and resolution of clearly defined categories of legal disputes whose termination is foreseen by the recent reform of the Court of Justice of the EU). Thus, in Treaty of Lisbon 2007, the names of elements of the judicial system of the EU as independent judicial bodies are brought in line with the logic implemented by them in different jurisdictional areas. Currently, the Court of Justice of the EU is the general name of the Court and the General Court as constituting elements of the EU judicial system, each of which ensures compliance with the right to interpretation and application of founding treaties within its own jurisdiction. However, sometimes, in the narrow sense, the EU Court calls the Court as the highest judicial authority in the EU, a functional institution of supranational and nonpolitical nature, acting on a permanent basis.

\section{Particularities of the legal status and jurisdiction of the Court of Justice of the EU}

The legal status and jurisdiction of the Court of Justice of the EU are enshrined in the founding treaties - Article 19 of the Treaty on European Union (TEU) as amended by the Treaty of Lisbon ${ }^{3} 2007$ (TEU-L) and detailed in

\footnotetext{
${ }^{3}$ Consolidated versions of the Treaty on European Union and the Treaty on the Functioning of the European Union. Official Journal of the European Union. C 202/01. Vol. 59.7 June 2016. P. 1-388. URL: https://eurlex.europa.eu/legal-content/EN/TXT/HTML/?uri=OJ:C:2016:202:FULL\&from=EN.
} 
Articles 251-281 of the Treaty on the Functioning of the European Union ${ }^{4}$ (TFEU), as well as in the updated Statute of the Court of Justice of the European Union contained in the annexed to the founding treaties Protocol on the Statute of the Court of Justice of the European Union provided for in Article 281 of the TFEU. The Court and the General Court, with the consent of the Court, each shall establish their own rules of procedure, which shall be subject to approval by the Council of the EU. The reform of the EU judicial system under the Treaty of Lisbon 2007 is limited, partially because the potential created by the Treaty of Nice in 2001 is not exhausted.

In the process of the Court of Justice of the EU evolution and its adaptation to new conditions and stages of integration process, its mandatory jurisdiction was confirmed. The main task that subjects jurisdiction of the Court of Justice of the EU is to ,ensure that in the interpretation and application of the Treaties the law is observed"5 (Article 19 (1) TEU-L), providing the same interpretation and application, unity and internal consistency of the EU law. The tasks assigned to them by the Court and the General Court are implementing through the exercise of justice within their own jurisdiction. The Court consists of one judge from each Member State. The General Court combines at least one judge from each Member State (Article 19 (2) TEU-L). The Court of Justice currently is assisted by eleven Advocates-General (the institute comes from the French court system). On the appeal of the Court, the Council of the EU Decision of June 25, 2013 2013/336 / EU, unanimously increased the number of Advocates-General to nine as from July 1, 2013, and to eleven as from October 7, 2015 ${ }^{6}$ (Member States agreed with this opportunity in a special Declaration No. 38, added to the Final Act of the Intergovernmental Conference on the Preparation of Treaty of Lisbon 2007). Besides, the current rotation system covers five (formerly three) Advocates-General. The main purpose of the Advocate-General as a special category of members of the Court is to publicly, acting with complete impartiality and independence to make, in open court, reasoned submissions on cases which, in accordance with the Statute of the Court of Justice of the European Union, require his involvement (Article 252 TFEU). Having previously an independent investigation of its materials, before the judges examined the case, the Advocate-General prepares his opinion on his own, and

\footnotetext{
${ }^{4}$ Consolidated versions of the Treaty on European Union and the Treaty on the Functioning of the European Union. Official Journal of the European Union. C 202/01. Vol. 59.7 June 2016. P. 1-388. URL: https://eurlex.europa.eu/legal-content/EN/TXT/HTML/?uri=OJ:C:2016:202:FULL\&from=EN.

${ }^{5}$ Consolidated versions of the Treaty on European Union and the Treaty on the Functioning of the European Union. Official Journal of the European Union. C 202/01. Vol. 59.7 June 2016. P. 1-388. URL: https://eur-lex.europa.eu/legal-content/EN/TXT/HTML/?uri=OJ:C:2016:202:FULL\&from=EN.

${ }^{6}$ Council Decision of 25 June 2013 increasing the number of Advocates-General of the Court of Justice of the European Union (2013/336/EU). Official Journal of the European Union. L 179. Vol. 56. 29 June 2013. P. 92. URL: https://eur-lex.europa.eu/LexUriServ/LexUriServ.do?uri=OJ:L:2013:179:FULL:EN:PDF.
} 
the judges make a decision collectively, acting as a single body. Judges are not obliged to adhere to the findings of Advocates-General, but mainly the Court makes judicial decisions that coincide with the opinions of the AdvocatesGeneral, this practice is recognized as indicative in terms of their high professional qualifications.

The Judges and Advocates-General of the Court of Justice, as well as the Judges of the General Court, are chosen from persons whose independence is beyond doubt and who meet the conditions laid down in Article 253, 254 TFEU and are subject to the provisions of Articles 11-14, 17 of the Protocol on the Privileges and Immunities of the EU, annexed to the Treaty of Lisbon 2007. They shall be appointed by common accord of the governments of the Member States for a term of six years, after consultation with a special qualification panel - the committee, first established under the Treaty of Lisbon 2007 for the purpose of more professional selection of candidates, to give an opinion on candidates' suitability to perform the duties of Judge and Advocate-General of the Court of Justice and the General Court before the governments of the Member States make the appointments referred to in Articles 253 and 254 TFEU. Every three years there shall be a partial replacement of the Judges and Advocates-General, in accordance with the conditions laid down in the Statute of the Court of Justice of the European Union. The Judges elect the President of the Court of Justice from among their number for a term of three years, his powers may be renewed. Retiring Judges and Advocates-General may be reappointed (Article 19 (2) TEU-L; Article 253 TFEU). The emergence of a pre-term vacancy can be caused by death or resignation, as well as exemption from functions performed by common accord with Judges and AdvocatesGeneral.

The Court can sit in chambers (of three or five judges), as a Grand Chamber (of fifteen judges) or may also sit as a full Court (28 judges), under the conditions laid down by the Statute. The court proceedings consist of two parts: written and oral. Within the framework of the written phase, the parties exchange documents, including evidence, through the Registrar of the Court. The oral procedure consists of the hearing by the Court of the Judge Rapporteur, of agents, advisers and lawyers and of the submissions of the Advocate-General, as well as the hearing of witnesses and experts, if any. The court may resort to special procedures, among which an expedited or accelerated procedure stand out. The judicial decision of the Court of Justice is made on behalf of the Court as a whole; is enforceable and is not subject to appeal. The internal working language and language of the meeting room is French. The Court functions within the regime of multilingualism, since all official documents are translated 
into 23 official languages of the EU, which are considered to be the languages of proceedings.

As opposed to the European Court of Human Rights, judges do not have right to ,separate opinion”, judges ad hoc are not appointed. It is noteworthy that the Court of Justice possesses the right, if it is required by the EU interests, to depart from previous judicial decisions. Thus, use of the doctrine of stare decisis is inappropriate to the activities of the Court of Justice, however, the high level of discretion for compliance with its established practice resembles more the doctrine jurisprudence constante, which is characterized by some flexibility.

The Court is authorized to consider the following categories of cases: on the failure of a Member State to fulfill obligation sunder EU law (Article 258-260 TFEU); on annulment of acts of EU institutions (Article 263, 264 TFEU); on establishment of the failure to act on the part of the institutions, bodies, agencies of the EU (Article 265 TFEU); on compensation based on non-contractual liability, that is, cases in which the EU make good any damage caused by its institutions or by its servants in the performance of their duties (Article 268 TFEU); on contractual liability, that is, cases transferred on the basis of arbitration clauses contained in a public-law contract or private-law contract concluded by the EU or on its behalf (Article 272 TFEU); in any dispute between the EU and its officials and other servants (Article 270 TFEU); to hear appeals on decisions given by the General Court determined at first instance (Article 256 (1, 3) TFEU); on jurisdiction to give preliminary rulings (Article 267 TFEU).

The Court of Justice of the EU exercises its jurisdiction in the following categories of proceedings: it rules on actions brought by a Member State, an institution or a natural or legal person; it gives preliminary rulings, at the request of courts or tribunals of the Member States, on the interpretation of EU law or the validity of acts adopted by the institutions; it rules in other cases provided for in the founding treaties (Article 19 (3) TEU-L). The Court of Justice of the EU monitors the legality, validity of legislative acts, of acts of the Council of the EU, of the European Commission and of the European Central Bank, other than recommendations and opinions that are not binding (Article 288 TFEU), of acts of the European Parliament and of the European Council, of the EU offices/agencies, intended to produce legal effects vis-à-vis third parties. For this purpose the Court of Justice of the EU shall have jurisdiction in actions brought by a Member State, the European Parliament, the Council of the EU or the European Commission on grounds of lack of competence, infringement of an essential procedural requirement, infringement of the founding treaties or of any rule of law relating to their application, or misuse of powers. Therefore, four possible grounds for challenging or annulling the acts of EU institutions, bodies, and agencies can be in the EU Court. On similar terms the Court of Justice of 
the EU shall have jurisdiction under the same conditions in actions brought by the Court of Auditors, by the European Central Bank and by the Committee of the Regions for the purpose of protecting their prerogatives. In the judgment of case 22/70 Commission v Council [1971] the Court provided a sufficient explanation "An action for annulment must therefore be available in the case of all measures adopted by the institutions, whatever their nature or form, which are intended to have legal effects"7 (p. 42). It is noteworthy that the agreements of services/divisions of EU institutions with the European External Action Service may intend to produce legal effects vis-à-vis third parties in accordance with Article 263 TFEU, enabling the European External Action Service to participate in the proceedings of the EU Court.

If, in breach of the founding treaties, the European Parliament, the European Council, the Council of the EU, the European Commission or the European Central Bank refrain from making a decision, including a legal act of the EU within the meaning of Article 288 of the TFEU, as well as EU bodies and agencies refrain from making a decision, EU Member States and institutions may apply to the EU Court to ensure that the violation is established. Any natural or legal person may, under the conditions laid down, may appeal to the EU Court of Justice against an act of any violation of his duties by EU institution, body, or agency in the form of non-acceptance of an act against this person, other than the recommendation/opinion, and may also sue against relevant applicable acts under the terms of Article 263 of the TFEU. In these cases, the EU Court may annul the act or establish the fact of inactivity (single practice) of the institution, body, agency, declaring it to be contrary to the founding treaties. As a consequence, the latter are obliged to take the measures necessary to implement the decision of the EU Court.

The Court of Justice of the EU can only deal with the matters of law, which were referred to it, and it is not authorized to decide on the matters of fact, as well as to apply the law to facts, which falls within the competence of national courts; in addition, national courts have competence over all categories of cases, except those that are assigned to jurisdiction of the Court of Justice of the EU. Its jurisdiction is extended to the area of freedom, security and justice (with the exception of the provisions of Article 276 TFEU), which is directly linked to the abolition of the EU pillar structure, to the interpretation and application of the Charter of Fundamental Rights of the European Union as adapted in $2007^{8}$. Charter of Fundamental Rights of the European Union is legally equivalent to

\footnotetext{
7 Case 22/70 Commission v Council [1971] ECR 00263. URL: https://eur-lex.europa.eu/legalcontent/EN/TXT/PDF/?uri=CELEX:61970CJ0022\&from=FI.

${ }^{8}$ Charter of Fundamental Rights of the European Union. Official Journal of the European Union. C 202/02. Vol. 59. 7 June 2016. P. 389-405. URL: https://eur-lex.europa.eu/legal-content/EN/TXT/HTML/ ?uri=OJ:C:2016:202:FULL\&from=EN.
} 
the founding treaties, is a source of primary EU law, "the completion of the European public order, inextricable part of which the protection of fundamental rights is" $"$.

\section{The evolution of the jurisdiction of the Court of Justice of the EU}

The Treaty of Lisbon 2007 substantively expanded jurisdiction of the Court of Justice of the EU, which, as a rule, covers all areas of integration association competence with the only exceptions that are expressly provided for by the founding treaties. Thus, the Court of Justice of the European Union shall not have jurisdiction with respect to the provisions relating to the Common Foreign and Security Policy nor with respect to acts adopted on the basis of those provisions with the exceptions set out in Article 275 (paragraph 2) of the TFEU. Consequently, in the future the EU Court will not monitor the validity of the acts of the European Council and the Council of the EU in this area adopted in accordance with Article 43 of the TEU-L. For example, decisions on joint disarmament operations, conflict prevention and peace-keeping tasks, tasks of combat forces in crisis management, EU civilian missions in the territory of third countries.

An important achievement of the Treaty establishing a Constitution for Europe 2004 (the international treaty on the first ever constitution of an integration association that has not entered into force but retains its historical and political significance), confirmed by Treaty of Lisbon 2007, was the extension of the content of the right of natural or legal persons to apply for protection to the EU Court. It is about allowing any natural or legal person to appeal, in particular, EU regulatory acts (Article 263 (paragraph 4) of the TFEU), for example regulations of the Council of the EU on fixed prices for agricultural products and other measures in the field of the common agricultural policy of the EU.

The Treaty of Lisbon 2007 extended the right to impose penalties on a Member State, in particular, if it has failed to fulfil its obligation to notify measures to the European Commission within the prescribed time for the "transposing" of the EU directive adopted in accordance with the legislative procedure (Article 260 (3) TFEU). If the Court finds that the Member State concerned has not complied with its judgment it may impose a lump sum or penalty payment on it (Article 260 (2; paragraph 2) TFEU). The contemporary approaches of the EU Court to the extraterritorial application of the EU law in the national legal order of third countries, evolution of jurisdictional models application practice, attract attention.

\footnotetext{
${ }^{9}$ Margaritis K. The Framework for Fundamental Rights Protection in Europe under the Prospect of EU Accession to ECHR. Journal of Politics and Law. Vol. 6. No. 1. 2013. P. 76.
} 
The General Court shall have jurisdiction to hear and determine at first instance actions or proceedings with the exception of those assigned to a jurisdiction of the Court. Decisions given by the General Court in accordance with Article 256 (1) TFEU, may be subject to a right of appeal to the Court of Justice on points of law only, - material/procedural, under the conditions and within the limits laid down by the Statute. Consequently, the Court may act as a court of first instance or in an appeal, ruling on cases decided by the General Court. The Court may confirm the judgment of the General Court, cancel it and refer the case for a new trial, cancel it and give judgment in the case. In the special questions under the conditions laid down by the Statute, the General Court is authorized to give preliminary rulings in accordance with Article 267 of the TFEU. Where the General Court considers that the case requires a decision of principle likely to affect the unity or consistency of EU law, it may refer the case to the Court of Justice for a ruling. Decisions given by the General Court on questions referred for a preliminary ruling may exceptionally be subject to review by the Court of Justice, under the conditions and within the limits laid down by the Statute, where there is a serious risk of the unity or consistency of EU law being affected (Article 256 (3) TFEU).

One of the main discussions accompanying the case law of the EU Court concerns the admissibility of judicial activism, that is, the Court's decision to go beyond the own jurisdiction. Judicial rulemaking, extension by the Court of its jurisdiction and interpretive creativity are considered to be manifestations of judicial activism. This is the position of the Court in the cases Van Gend en Loos, Costa, Foto-Frost, Francovich, Chernobyl, Melloni, Fransson and others. Criticism is primarily due to the conviction that the phenomenon of activism was the result of gaps, uncertain and abstract formulations of founding treaties, strengthening the competence of the EU and infringing on the sovereignty of Member States for a weak system of checks and balances. Judicial activism is not always perceived by society, while it has a significant impact on gradually complicated integration processes.

\section{The impact of judicial practice on the autonomization of the EU legal order}

The EU legal order is autonomous; the activities of the Court of Justice played a decisive role in filling this concept, as well as many others, with legal content and conceptional provision. The evolution of EU legal order affects methodology of interpretation and practice of applying the EU law to the Court of Justice of the EU and, on the contrary, judicial practice has impact on the autonomization and constitutionalization of the EU legal order, the dynamics of its development, unity and integrity. One of essential results of the Court of 
Justice activities is determination of mode of action of community law and of peculiarities of the nature of the legal system of the $\mathrm{EU}^{10}$. In the judgment of the case 26/62 Van Gend en Loos [1963] the Court introduced for the first time the principle of direct effect of EU law rule in internal legal orders of Member States, having issued decree that they could be applied in the national courts along with the rules of national legislation during proceedings ${ }^{11}$. Professor V. I. Muravyov emphasizes that "the rules of EU law of direct effect do not require the concretization or refinement for their realization"12, "The rules of direct effect contained in acts of EU law must be distinguished from the selfgoverning norms of international treaties. They have different implementation mechanisms"13.

The Court of Justice of the EU establishes which of the norms of the EU law have direct effect, since it has the competence in formally interpreting the founding treaties and the law created by the EU based on the founding treaties. Actually, ,the clarification of the content of the legal norm, the elimination of gaps in the founding treaties, their specification in the law of the EU is carried out not only through the adoption of acts of secondary law, but also by way of judicial interpretation" 14 . It is notable that the Court of Justice of the EU has the right to interpret the Copenhagen criteria of EU membership, if necessary, as it was legally recognized in Article 49 (1) TEU-L.

In the judgment of the case 6/64 Costa $v$ ENEL [1964] clearly stipulates functional principle of EU law supremacy (primacy) over domestic law of Member States ${ }^{15}$, which determines the autonomous character of EU legal order and supranational level of legal regulation. The primacy of the EEC law has been consistently confirmed by the Court's rulings, in particular in case 106/77 Simmenthal [1978], in which the conclusion that non-application of domestic law which may conflict with the Community law was developed to the need to retain Member States from adopting national legal acts which conflict with the

\footnotetext{
${ }^{10}$ Craig P. The Lisbon Treaty. Law, Politics and Treaty Reform. New York : Oxford University Press, 2010. P. 195-196.

${ }_{11}$ Case 26/62 Van Gend en Loos [1963] ECR 1. URL: http://eur-lex.europa.eu/legalcontent/EN/TXT/?uri=CELEX\%3A61962CJ0026.

12 Муравьев В.И. Реализация норм права Европейского Союза во внутренних правопорядках государств-членов. Международное право как основа современного миропорядка. Liber Amicorum $\kappa$ 75летию проф. В.Н. Денисова : монография /Под ред. А.Я. Мельника, С.А. Мельник, Т.Р. Короткого. Киев; Одесса : Фенікс, 2012. С. 327.

${ }_{13}^{13}$ Муравйов B.I. Механізм реалізації норм права Європейського союзу у правопорядках державчленів. Украӥнський часопис міжнародного права. 2012. № 1. С. 87.

${ }_{14}^{14}$ Яворська I., Микієвич М. Суд Європейського Союзу: правовий статус та особливості реалізації правотворчої функції : монографія. Львів : ЛНУ імені Івана Франка, 2017. С. 207.

15 Case 6/64 Costa v ENEL [1964] ECR 585. URL: http://eur-lex.europa.eu/legalcontent/EN/TXT/?uri=CELEX\%3A61964CJ0006.
} 
Community law ${ }^{16}$. It is noteworthy that the integrated of EU law into the internal law of the Member States does not contradict its autonomy, since it remains a sui generis legal order, independent for the legal order of the Member States.

The judicial practice of the Court demonstrates the tendency to complete separation of the EU law from general international law and EU legal order from the international legal order. In the joined cases C-402/05P, C-415/05P Kadi and Al Barakaat International Foundation v Council and Commission [2008] (Kadi-I) the Court, in particular, clarified the relationship between EU law and international obligations related to membership in the United Nations, recognized the violation of the right to respect for property, the right to be heard, the right to an effective remedy. It is noteworthy that, in a collision situation, the Court favored the EU law thus departing from its previous practice (cases C-286/90 Anklagemyndigheden $v$ Peter Michael Poulsen \& Diva Navigation Corp. [1992]; C-162/96 A. Racke GmbH \& Co. v Hauptzollamt Mainz [1998]). The appellants appealed against the judgments of the Court of First Instance, dated September 21, 2005, in which he declined to comply with their claims. The Court found that an international agreement cannot affect the allocation of powers fixed by the founding treaties or, consequently, the autonomy of the EU legal system, observance of which is ensured by the Court (paragraph 282). Judicial control of an EU act to respect fundamental rights, including an act adopted in pursuance of Security Council resolutions, the review by the Court of its validity must be considered to be a guarantee of an autonomous legal system of EU, which is not to be prejudiced by an international agreement (paragraph 316$)^{17}$.

Finally, taking into account the above arguments, the Court satisfied the demands by cancelation of appealed decisions of the Court of First Instance and invalidating the disputed Council Regulation (EC) 881/2002 of 27 May 2002 imposing certain restrictive measures directed against certain persons and entities associated with Usama bin Laden, the Al-Qaeda network and the Taliban in the part concerning the appellants ${ }^{18}$. Thus, the Court's legal position is that the EU seeks to protect its values, including the European standards for the protection of fundamental rights, regardless whether it will lead to an indirect refusal to comply with the requirements of the Security Council, the obligations under the Charter of the United Nations, which is a controversial decision in the context of general international law. The position of the Court is

\footnotetext{
16 Case 106/77 Simmenthal [1978] ECR 629. URL: http://eur-lex.europa.eu/legalcontent/EN/TXT/?uri=CELEX\%3A61977CJ0106.

17 Joined cases C-402/05P and C-415/05P Kadi and Al Barakaat International Foundation v Council and Commission [2008] ECR I-06351. URL: http://eur-lex.europa.eu/legal-content/HR/ALL/?uri=CELEX: 62005 CJ0402.

${ }^{18}$ Joined cases C-402/05P and C-415/05P Kadi and Al Barakaat International Foundation $v$ Council and Commission [2008] ECR I-06351. URL: http://eur-lex.europa.eu/legal-content/HR/ALL/?uri= CELEX:62005CJ0402.
} 
generally recognized as posing a threat to the unity of international law and will inevitably affect the fragmentation of international law. Of course, the EU's legal order differs from the international one, but it can not run counter to the basic principles of international law in accordance with the UN Charter and the jus cogens.

The Kadi-I judgment is an illustrative example of the impact on the development of the EU law of judicial practice, its ambiguity both in the area of the protection of fundamental rights and the establishment of the autonomy of the EU's legal order, its preservation and strengthening as a new legal order, separate from international law, serving as one of the manifestations of fragmentation of the latter.

\section{Autonomous interpretation and preliminary ruling procedure}

The EU legal order does not depend on national legal orders of the Member States, however it works in conjunction with them, which is manifested in activities of Court of Justice of the EU, in particular in the form of preliminary ruling procedure, that is one of its most implemented function. According to Article 267 of the TFEU and Article 19 (3b) TEU-L, the Court of Justice of the EU has jurisdiction to give preliminary ruling procedure concerning the interpretation of the founding treaties and the validity and interpretation of acts of the institutions, bodies, offices or agencies of the EU. If any court or tribunal of the Member State, in case of necessity to apply EU law to particular case, considers that a decision on the question is necessary to enable it to give judgment, it may refer the case to the Court for a preliminary ruling; thus, they cooperate, maintaining a permanent connection, in the absence of a hierarchical subordination (joined cases 28-30/62 Da Costa en Schaake NV, Jacob Meijer NV, Hoechst-Holland NV v Netherlands Inland Revenue Administration [1963]; cases 283/81 Srl CILFIT v Ministry of Health [1982]; C-344/04 The Queen v Department for Transport [2006]; C-22/11 Finnair Oyj v TimyLassooy [2012]). If the above question is raised in a matter pending before a court or tribunal of the Member State, whose decision there is no judicial remedy under national law, that authority is required to apply to the Court of Justice within the framework of the preliminary rulings procedure. For the period of consideration of the request in preliminary ruling, which is sometimes prolonged, proceedings in the case are suspended in the national court or tribunal. Noteworthy that in the case of 283/81 Srl CILFIT and Lanificio di Gavardo SpA $v$ the Ministry of Health [1982], adopted at the request of the Italian court, formulated criteria under which even the national court or tribunal of last instance does not have the obligation to initiate the preliminary ruling. "The correct application of community law may be so obvious as to leave no scope for any reasonable doubt 
as to the manner in which the question raised is to be resolved. Before it comes to the conclusion that such is the case, the national court or tribunal must be convinced that the matter is equally obvious to the courts of the other Member States and to the Court of Justice. Only if those conditions are satisfied, may the national court or tribunal refrain from submitting the question to the Court of Justice and take upon itself the responsibility for resolving it" (paragraph 16) ${ }^{19}$.

Preliminary ruling procedure is aimed to prevent divergent interpretations of EU law in judicial practice and is recognized as the cornerstone of EU legal order and as exceptionally important factor of European integration, which update increase of its efficiency. Under Article 3 (2) of Regulation 2015/2422 of the European Parliament and of the Council of 16 December 2015, changes to the distribution of competence for preliminary ruling are possible ${ }^{20}$. The judgments are legally binding as well as the judgments on proceedings of direct claims. In other words, the court or tribunal of Member State is bound by the interpretation given. „The decision of the Court of Justice has ex tunc effect; i.e. since the particular act has been adopted" ${ }^{21}$.

\section{Reformation of the Court of Justice of the $E U$}

The President of the Court, in an official appeal dated March 28, 2011, to the European Parliament and the Council of the EU initiated the reform of the EU judicial system in view of the existing problems in its functioning, justifying the proposal to amend the Statute of the Court of Justice by adopting the relevant Regulation. The post-Lisbon reform period of the EU Court was initiated by the European Parliament and the Council of the EU, in particular, under Article 254 (paragraph 1) and Article 281 (paragraph 2) of the TFEU acting in accordance with the ordinary legislative procedure, Regulation 2015/2422 of 16 December $2015^{22}$, amending the Statute of the Court of Justice of the EU, as a consequence of the progressive expansion of its jurisdiction since its creation, the constant workload of the branched-out judicial system EU, an increase in the number of cases that complicates their public hearing within a reasonable time as required by Article 47 of the Charter of Fundamental Rights of the European Union as

\footnotetext{
${ }^{19}$ Case 283/81 Srl CILFIT v Ministry of Health [1982] ECR 03415. URL: https://www.cvce.eu/content/ publication/1999/1/1/d3cb219e-ab06-4ae9-b37c-2b2e4c47c60d/publishable_en.pdf

${ }^{20}$ Regulation (EU, Euratom) 2015/2422 of the European Parliament and of the Council of 16 December 2015 amending Protocol № 3 on the Statute of the Court of Justice of the European Union. Official Journal of the European Union. L 341. 24 December 2015. P. 14-17. URL: https://eur-lex.europa.eu/eli/reg/2015/2422/oj.

${ }^{21}$ Hamul'ák O., Stehlik V. European Union Constitutional Law: Revealing the Complex Constitutional System of the European Union. Olomouc : Palacky University Olomouc, 2013. P. 138.

${ }^{22}$ Regulation (EU, Euratom) 2015/2422 of the European Parliament and of the Council of 16 December 2015 amending Protocol № 3 on the Statute of the Court of Justice of the European Union. Official Journal of the European Union. L 341. 24 December 2015. P. 14-17. URL: https://eur-lex.europa.eu/eli/reg/2015/2422/oj.
} 
adapted in 2007 and Article 6 of the European Convention for the Protection of Human Rights and Fundamental Freedoms of 1950.

The situation in which the General Court finds itself has causes relating to the increase in the number and variety of legal acts of the institutions, bodies, offices and agencies of the EU, as well as to the volume and complexity of the cases brought before the General Court, particularly in the areas of competition, State aid and intellectual property. To solve this situation suitable measures of an internal reorganization of the General Court, in particularof structural nature, should be taken that should not lead to the recruitment of additional secretaries or other auxiliary staff, but should ensure effective use and equal conditions for available human resources that should be equal for all judges. Instead of setting up specialised courts with special jurisdiction in compliance with the conditions and procedures laid down in Article 257 TFEU,the new wording of Article 48 of the Statute of the Court of Justice of the EU provides for the gradual increase of the General Court's quantitative parameters (40 Judges as from 25 December 2015, 47 Judges as from 1 September 2016, two Judges per Member State as from 1 September 2019) for a reduction of the excessive duration of proceedings, for improving the efficiency of justice at the EU and other levels, which is in line with current trends. In addition to independence, impartiality, experience, the professional and personal suitability of the candidates for high judicial positions, henceforth, gender balance among candidates for the position of judge is of high importance.

\section{CONCLUSIONS}

Adapting to the new imperatives, conditions and stages of the integration process, the organizational and legal fundamentals of the Court of Justice of the $\mathrm{EU}$, its approaches to interpretation, taking into account the existing models and the current status of law, are being developed; which sensu stricto does not preclude legal certainty as a fundamental part of the rule of law principle. The Court got the confidence, established as an influential institution of the EU, and ensured: effective judicial protection in the areas of EU law regulation, having formulated its main qualification features; the correct application of EU acquis, partly filled with Court practice; the progress of European integration, including the deepening of legal integration; maintenance and observance of the institutional balance established by the founding treaties; the high authority of the judicial decisions that have become an important source of EU law, consistently contributing to its evolutionary development and at the same time establishing, maintaining and strengthening of the legal order of the EU as a sui generis legal order, its autonomy. 
The judicial practice of EU law interpretation is a multidimensional phenomenon, an effective factor in deepening European integration. It is committed to ensure that in the interpretation and application of the founding treaties the law is observed; the uniform interpretation and application, as well as unity and internal consistency of EU law. All of the mentioned have a significant impact on the autonomy of the EU legal order and its constitutionalization.

The foregoing has an applied value for intensifying strategically resultoriented multidimensional cooperation between Ukraine and the EU, increasing its efficiency, since it allows not only to gain a better understanding of the peculiarities of the functioning and reformation of the EU judicial system, autonomization and constitutionalization of the EU law order, as well as to assess risks and take into account the benefits of the process of realization of European integration.

\section{SUMMARY}

The peculiarities of the legal status and evolution of jurisdiction, the postLisbon period of the Court of Justice of the EU reformation, and its role in autonomization of the EU legal order were highlighted in the research. It was noted that at present the Court of Justice of the EU is a generalized title of the Court and the General Court as constituent elements of the judicial system of the integration association, each of them within its jurisdiction ensures observance of the right that in the interpretation and application of the founding treaties.

The role of the practice of the Court of Justice of the EU in the process of formation and development of the EU law, the formation and autonomization of sui generis legal order is emphasized. The author noted that the EU legal order does not depend on the national legal orders of the Member States, but interacts with them, which is appeared also in the work of the Court of Justice of the EU, in particular in the form of a preliminary interpretation. The preliminary ruling procedure is recognized as an extremely important factor of integration, which actualizes the increase of its efficiency.

It was stated in the research that adapting to the new imperatives, conditions and stages of the integration process, the organizational and legal fundamentals of the Court of Justice of the EU, its approaches to interpretation, taking into account the existing models and the current status of law, are being developed; which sensu stricto does not preclude legal certainty as a fundamental part of the rule of law principle.

The Court got the confidence, established as an influential institution of the EU, and ensured: effective judicial protection in the areas of EU law regulation, having formulated its main qualification features; the correct application of EU 
acquis, partly filled with Court practice; the progress of European integration, including the deepening of legal integration; maintenance and observance of the institutional balance established by the founding treaties; the high authority of the judicial decisions that have become an important source of EU law, consistently contributing to its evolutionary development and at the same time establishing, maintaining and strengthening of the EU legal order as a sui generis legal order, its autonomization and constitutionalization.

\section{REFERENCES}

1. Case 106/77 Simmenthal [1978] ECR 629. URL: http://eur-lex.europa.eu/legal-content/EN/TXT/?uri=CELEX\%3A61977CJ0106.

2. Case 22/70 Commission $v$ Council [1971] ECR 00263. URL : https://eur-lex.europa.eu/legalcontent/EN/TXT/PDF/?uri=CELEX:61970CJ0022\&from=FI.

3. Case 26/62 Van Genden Loos [1963] ECR 1. URL: http://eur-lex.europa.eu/legal-content/EN/TXT/?uri=CELEX\%3A61962CJ0026.

4. Case 283/81 Srl CILFIT v Ministry of Health [1982] ECR 03415. URL: https://www.cvce.eu/content/publication/1999/1/1/d3cb219e-ab06-4ae9-b37c2b2e4c47c60d/publishable_en.pdf.

5. Case 6/64 Costa $v$ ENEL [1964] ECR 585. URL: http://eurlex.europa.eu/legal-content/EN/TXT/?uri=CELEX\%3A61964CJ0006.

6. Chalmers D., Davies G., Monti G. European Union Law: Text and Materials. 3rd ed. Cambridge : Cambridge University Press, 2014. 1220 p.

7. Charter of Fundamental Rights of the European Union. Official Journal of the European Union. C 202/02. Vol. 59. 7 June 2016. P. 389-405. URL: https://eur-lex.europa.eu/legal-

content/EN/TXT/HTML/?uri=OJ:C:2016:202:FULL\&from=EN.

8. Consolidated versions of the Treaty on European Union and the Treaty on the Functioning of the European Union. Official Journal of the European Union. C 202/01. Vol. 59. 7 June 2016. P. 1-388. URL: https://eur-lex.europa.eu/legalcontent/EN/TXT/HTML/?uri=OJ:C:2016:202:FULL\&from=EN.

9. Council Decision of 25 June 2013 increasing the number of AdvocatesGeneral of the Court of Justice of the European Union (2013/336/EU). Official Journal of the European Union. L 179. Vol. 56. 29 June 2013. P. 92. URL: https://eur-

lex.europa.eu/LexUriServ/LexUriServ.do?uri=OJ:L:2013:179:FULL:EN:PDF.

10. Craig P. The Lisbon Treaty. Law, Politics and Treaty Reform. New York : Oxford University Press, 2010. 466 p.

11. Greer S., Gerards J., Slowe R. Human Rights in the Council of Europe and the European Union: Achievements, Trends and Challenges. Cambridge: Cambridge University Press, 2018. 560 p. 
12. Hamul'ák O., Stehlik V. European Union Constitutional Law: Revealing the Complex Constitutional System of the European Union. Olomouc: Palacky University Olomouc, 2013. 204 p.

13. Joined cases C-402/05P and C-415/05P Kadi and Al Barakaat International Foundation $v$ Council and Commission [2008] ECR I-06351. URL: http://eur-lex.europa.eu/legal-content/HR/ALL/?uri=CELEX: 62005 CJ0402.

14. Margaritis K. The Framework for Fundamental Rights Protection in Europe under the Prospect of EU Accession to ECHR. Journal of Politics and Law. Vol. 6. No.1. 2013. P. 64-79.

15. Regulation (EU, Euratom) 2015/2422 of the European Parliament and of the Council of 16 December 2015 amending Protocol № 3 on the Statute of the Court of Justice of the European Union. Official Journal of the European Union. L 341. 24 December 2015. P. 14-17. URL: https://eur-lex.europa.eu/eli/reg/2015/2422/oj.

16. Regulation (EU, Euratom) 2016/1192 of the European Parliament and of the Council of 6 July 2016 on the transfer to the General Court of jurisdiction at first instance in disputes between the European Union and its servants. Official Journal of the European Union. L 200. 26 July 2016. P. 137-139. URL: https://eur-lex.europa.eu/eli/reg/2016/1192/oj.

17. Муравйов B.I. Механізм реалізації норм права Європейського союзу у правопорядках держав-членів. Украйнський часопис міжнародного права. 2012. № 1. С. 83-90.

18. Муравьев В.И. Реализация норм права Европейского Союза во внутренних правопорядках государств-членов. Международное право как основа современного миропорядка. Liber Amicorum к 75-летию проф. B.Н. Денисова : монография. Под ред. А.Я. Мельника, С.А. Мельник, Т.Р. Короткого. Киев; Одесса : Фенікс, 2012. С. 310-327.

19. Яворська І., Микієвич М. Суд Свропейського Союзу: правовий статус та особливості реалізації правотворчої функції : монографія. Львів : ЛНУ імені Івана Франка, 2017. 248 с.

\section{Information about author:} Falalieieva L. H., Candidate of Juridical Sciences, Associate Professor, Ph.D. Candidate, Department of International Law and Comparative Law, V. M. Koretsky Institute of State and Law of the National Academy of Sciences of Ukraine 4 Trjohsvjatitelska st., Kyiv, Ukraine 